浸潤性乳腺小葉癌の臨床病理学的および診断学的検討

一その他の浸潤癌と比較して一

長野県がん検診センター検診部, 病理部*
小池 綏 男 寺 井直 樹 若 林 透 土 屋真一*

過去10年 3 力月間に長野県がん検診センターの乳腺外来で診断した浸潤性小葉癌30例 とその他の浸潤癌419例を臨床病理学的および診断学的に比䂭検討した.年歯的には浸潤 性小葉癌の方がやや若い傾向がみられた，腫瘤の大きさ，病期などからみると，浸潤性 小葉癌はその他の浸潤癌より進行例が多い印象を受けたが, リンパ節転移は陰性例が多 かった. 浸潤性小葉癌はその他の浸潤癌より触診で診断することが難しく, mammography より ultrasonography の方が有用であることが筧われた。呀刺吸引細胞診で悪性を 疑った割合はその他の浸潤癌の $94.2 \%$ に対して浸潤性小葉癌は $75.0 \%$ 低かったが，他 の診断法と比べると有意に高かった。また，穿刺感による診断も有用であることが示唆 された，以上, 乳腺疾患の診察に際しては, 浸潤性小葉癌も念頭において, 諸検査の他 に穿刺感も参考にして診断することが有用であると考える.

索引用語: 乳癌, 浸潤性小葉癌, 臨床病理学的所見, 診断学的所見

\section{緒言}

乳腺の浸潤性小葉癌の頻度はそれほど多くないが, 近年，わが国では増加する傾向にある ${ }^{1)}$.したがって， 浸潤性小葉癌の特徵を知ることは, 乳癌の診断上, 有 意義である.そこで，今回は，本センターで診断した 乳癌症例中の浸潤性小葉癌をその他の浸潤癌と臨床病 理学的および診断学的に比較検討し, 両群間に若干の 差異を認めたので報告する.

\section{研究対象および方法}

長野県がん検診センターの乳腺外来では，視・触診 に, 原則として mammography (MG), ultrasonography (US), thermography (TG) を併用し, 腫瘤を触 知した症例には積極的に穿刺吸引細胞診を行って診断 を確定しているが2)，確診できない場合には $3 \sim 6 力$ 月後に再検し,症例によっては生検を行っている.1983 年10月から1993年までの10年3カ月間に診断した女性 乳癌は 479 例, 485 病変 (両側性乳癌 6 例の両側を独立 させた12病変中， 6 病変は浸潤性小葉癌であった）で あった。これらの症例中の浸潤性小葉癌（以下小葉癌 と略) 30例と，その他の浸潤癌419例 (浸潤性乳管癌393 例十特殊型浸潤癌 26 例：以下浸潤癌と略）の初診時の

1995年 3 月 6 日受付 1995 年 8 月11日採用
表 1 乳癌症例

(1983年10月～1993年12月)

\begin{tabular}{|c|c|c|}
\hline 組繏分類 & \multicolumn{2}{|c|}{ 症例数\# } \\
\hline 非浸潤癌 & \multicolumn{2}{|l|}{$16(3.3 \%)$} \\
\hline 浸潤性乳管癌 & \multicolumn{2}{|c|}{$393(81.0 \%), 419$} \\
\hline 特殊型浸潤癌 & \multicolumn{2}{|c|}{$26(5.4 \%)(86.4 \%)$} \\
\hline ・浸潤性小葉癌 & \multicolumn{2}{|c|}{$30(6.2 \%)$} \\
\hline Paget 癌 & \multicolumn{2}{|l|}{$3(0.6 \%)$} \\
\hline 異所性乳癌 & \multicolumn{2}{|l|}{$2(0.4 \%)$} \\
\hline 線維腺腫内癌 & \multicolumn{2}{|l|}{$2(0.4 \%)$} \\
\hline 組織型不明 & \multicolumn{2}{|l|}{$13(2.7 \%)$} \\
\hline 計 & \multicolumn{2}{|l|}{$485(100 \%)$} \\
\hline \multicolumn{3}{|c|}{$\begin{array}{l}\# \text { \#:両側性乳癌 } 6 \text { 例の両則を独立させて12例 } \\
\text { として扱った. }\end{array}$} \\
\hline \multicolumn{2}{|c|}{ 浸潤性小葉癌＋浸潤性小葉癌 } & 2 例 \\
\hline \multicolumn{2}{|c|}{ 浸潤性小葉癌＋浸潤性乳管癌 } & 1 例 \\
\hline \multicolumn{2}{|c|}{ 浸潤性小葉癌十特殊型浸潤癌 } & 1 例 \\
\hline \multicolumn{2}{|c|}{ 浸潤性乳管癌＋浸潤性乳管癌 } & 2 例 \\
\hline
\end{tabular}

臨床所見と各種診断および手術後の病理組織学的所見 を比較検討した(表 1). なお，有意差検定は $\chi^{2}$ 検定に よって行った。また, 画像診断は表 2 のような I (異 常なし）からV (悪性) までの 5 段階表示の診断法を 用い, 穿刺吸引細胞診は Papanicolaou の分類を用い 


\section{表 2 画像喨断の診断基準}

I：異常所見を認めないもの.

II：良性と考えられるもの。

III：良・悪の区別が困難であるもの.

IV : 墨性が濃厚であるもの.

$\mathrm{V}$ ：要性(洗)と考えられるもの。

て診断した.

\section{1. 臨床病理学的検討 \\ 1）年齢別頻度（表 3 )}

成 績

小葉癌は 40 歳代が $50.0 \%$ と半数を占め,ついで, 50 歳代 $23.3 \% ， 60$ 歳代 $13.3 \%$ の順であり，浸潤癌も同様 な年代順に多かったが，40歳代の頻度は小葉癌の方が 統計学的に有意 $(\mathrm{p}<0.05)$ に多かった。年齢分布をみ ると, 小葉癌は37歳から77歳であり, 浸潤癌は22歳か ら88歳であった。平均年齢はそれぞれ50.0歳と52.7歳 で，小葉癌の方がやや若い傾向がみられた。

\section{2）腫瘤の大きさ (表 4 )}

小葉癌では $2.0 \mathrm{~cm}$ 以下が $16.7 \%$ と浸潤癌の $25.5 \%$ に比べて少なく，5.1cm 以上の大きな症例が $26.7 \%$ と，浸潤癌の $14.6 \%$ より多い傾向がみられたが，統計

表 3 年齢別頻度

\begin{tabular}{|c|c|c|}
\hline 年齢 (歳) & 浸潤性小葉癌 & 浸潤癙 \\
\hline$\sim 29$ & 0 & $3(0.7 \%)$ \\
\hline$\sim 39$ & $2(6.7 \%)$ & $49(11.7 \%)$ \\
\hline$\sim 49$ & $15(50.0 \%) *$ & $129(30.8 \%)$ \\
\hline$\sim 59$ & $7(23.3 \%)$ & $120(28.6 \%)$ \\
\hline$\sim 69$ & $4(13.3 \%)$ & $90(21.5 \%)$ \\
\hline$\sim 79$ & $2(6.7 \%)$ & $19(4.5 \%)$ \\
\hline $80 \sim$ & 0 & $9(2.1 \%)$ \\
\hline 計 & $30(100 \%)$ & $419(100 \%)$ \\
\hline 年齢分布 & $37 \sim 77$ 歳 & $22 \sim 88$ 歳 \\
\hline 平均年柃 & 50.5 葴 & 52.7 歳 \\
\hline
\end{tabular}

表 4 腫瘤の大きさ

\begin{tabular}{c|c|c}
\hline 大きさ $(\mathrm{cm})$ & 浸潤小葉癌 & \multicolumn{1}{|c}{ 浸閏癌 } \\
\hline$\sim 2.0$ & $5(16.7 \%)$ & $107(25.5 \%)$ \\
$\sim 5.0$ & $17(56.7 \%)$ & $251(59.9 \%)$ \\
$5.1 \sim$ & $8(26.7 \%)$ & $61(14.6 \%)$ \\
\hline 計 & $30(100 \%)$ & $419(100 \%)$ \\
\hline
\end{tabular}

学的には有意差は認めなかった。

\section{3）病期分類（表 5)}

両群ともに Stage II が50\%強であった. Stage I は 小葉癌は $10.0 \%$ と浸潤癌の $24.1 \%$ より少なく, Stage IIIa は逆に，浸潤癌の $16.7 \%$ に対して小葉癌は $26.7 \%$ と多い傾向がみられた。葉癌には Stage IIIb 以上の 症例はなかった。

\section{4）癌型の割面肉眼分類（表 6)}

小葉癌では浸潤型が $63.3 \%$ と最も多く，ついで，分 類不能型が20.0\%で, 限局型は6.7\%と少なかった。浸 潤癌も浸潤型が $44.9 \%$ と多かったが，つぎは，限局型 の $23.9 \%$ て 分類不能型は $7.2 \%$ と少なかった。分類不 能型の割合は小葉癌と浸潤癌の間に統計学的に有意差 ( $\mathrm{p}<0.05)$ を認めた。

5）浸潤澏の波及程度（表 7)

小葉癌ではfが73.3\%と最も多く,ついで，gが

表 5 病期分類

\begin{tabular}{c|c|r}
\hline 病 期 & 浸潤性小葉癌 & \multicolumn{1}{|c}{ 浸潤癌 } \\
\hline 0 & $2(6.7 \%)$ & $8(1.9 \%)$ \\
I & $3(10.0 \%)$ & $101(24.1 \%)$ \\
II & $17(56.7 \%)$ & $224(53.5 \%)$ \\
IIIa & $8(26.7 \%)$ & $70(16.7 \%)$ \\
IIIb & 0 & $12(2.9 \%)$ \\
IV & 0 & $4(1.0 \%)$ \\
\hline 計 & $30(100 \%)$ & $419(100 \%)$ \\
\hline
\end{tabular}

表 6 癌型の割面肉眼分類

\begin{tabular}{|c|c|c|}
\hline 肉眼分類 & 浸潤性小葉癌 & 浸潤癌 \\
\hline 限 局 型 & $2(6.7 \%)$ & $100(23.9 \%)$ \\
\hline 中 間 型 & $3(10.0 \%)$ & $96(22.9 \%)$ \\
\hline 浸 潤 型 & $19(63.3 \%)$ & $188(44.9 \%)$ \\
\hline 分類不能型 & $6(20.0 \%) *$ & $30(7.2 \%)$ \\
\hline 不 & 0 & $5(1.2 \%)$ \\
\hline 計 & $30(100 \%)$ & $419(100 \%)$ \\
\hline
\end{tabular}

表 7 癌漫瀾の波及程度

\begin{tabular}{c|c|r}
\hline 分 類 & 漫潤性小葉癌 & \multicolumn{1}{|c}{ 漫潤癌 } \\
\hline $\mathrm{g}$ & $7(23.3 \%)$ & $87(20.8 \%)$ \\
$\mathrm{f}$ & $22(73.3 \%)$ & $317(75.7 \%)$ \\
$\mathrm{s}, \mathrm{p}$ & $1(3.3 \%)$ & $11(2.6 \%)$ \\
不 明 & 0 & $4(1.0 \%)$ \\
\hline 計 & $30(100 \%)$ & $419(100 \%)$ \\
\hline
\end{tabular}


表 8 リンパ節転移の程度分類

\begin{tabular}{|c|c|c|}
\hline $\mathrm{n}$ 分類 & 浸潤性小集癌 & 浸潤癌 \\
\hline no & $21(70.0 \%)$ & $260(62.1 \%)$ \\
\hline $\mathrm{n} l \alpha$ & $5(16.7 \%)$ & $79(18.9 \%)$ \\
\hline $\mathrm{nl} \beta$ & $1(3.3 \%)$ & $39(9.3 \%)$ \\
\hline $\mathrm{n} 2$ & $2(6.7 \%)$ & $21(5.0 \%)$ \\
\hline n3 & 0 & $15(3.6 \%)$ \\
\hline 不明 & $1(3.3 \%)$ & $3(0.7 \%)$ \\
\hline 郭清(一) & 0 & $2(0.5 \%)$ \\
\hline 計 & $30(100 \%)$ & $419(100 \%)$ \\
\hline \multicolumn{3}{|c|}{ n0：リンパ節転移陰性例. } \\
\hline \multicolumn{3}{|c|}{$\mathrm{n} 1 \alpha$ ：転移陽性第 1 群リンパ節が 3 個以内. } \\
\hline \multicolumn{3}{|c|}{$\mathrm{n} 1 \beta$ ：転移陽性第 1 群リンパ節が 4 個以上. } \\
\hline \multicolumn{3}{|c|}{ n2 ：第 2 群リンパ節転移陽性. } \\
\hline \multicolumn{3}{|c|}{$\mathrm{n} 3$ ：第 3 群リンパ節転移陽性。 } \\
\hline
\end{tabular}

表 9 触診診断

\begin{tabular}{|c|c|c|}
\hline 診断名 & 浸潤性小葉癌 & 浸潤癌\# \\
\hline 乳 癌 & $6(20.0 \%)$ & $165(39.5 \%)$ \\
\hline 乳癌疑い & $15(50.0 \%)$ & $136(32.5 \%)$ \\
\hline 線維腺腫 & 0 & $27(6.5 \%)$ \\
\hline 乳 腺 症 & $7(23.3 \%)$ & $72(17.2 \%)$ \\
\hline 軎胞 & 0 & $6(1.4 \%)$ \\
\hline その他 & $2(6.7 \%)$ & $12(2.9 \%)$ \\
\hline 計 & $30(100 \%)$ & $418(100 \%)$ \\
\hline
\end{tabular}

\#：他医生検例 1 例を除く。

23.3\%であった．浸潤癌もほほ同様であり，両群間に 差がみられなかった。

6）リンパ節転移の程度分類（表 8)

小葉癌では n0が70.0\%であって, 浸潤癌の $62.1 \%$ よ り多い傾向がみられた， $1 \alpha$ は差がみられなかった が, $\mathrm{n} 1 \beta$, および $\mathrm{n} 3$ は浸潤癌の方が多かった。

\section{2. 診断学的検討}

1) 触診診断（表 9)

小葉癌は触診では $50.0 \%$ が乳癌疑いと診断され, 乳 腺症が23.3\%で，乳癌と診断された割合は $20.0 \% て$ あった。それに対し，浸潤癌は乳癌と診断された割合 は39.5\%であり，ついで，乳癌疑いが32.5\%，乳腺症 が17.2\%であった。両群間に有意差は認めなかった。

\section{2) Mommography 診断（表10）}

小葉癌は mammography で MGV，あるいは MGIV と診断された割合は26.7\%であったが, 浸潤癌は $48.2 \%$ と統計学的に有意 $(\mathrm{p}<0.05)$ に多かった. MGII，あるいは MGI と診断された割合は小葉癌では
表10 Mammography 診断

\begin{tabular}{|c|c|c|}
\hline MG 診断 & 浸潤性小葉癌 & 浸潤泹 \\
\hline $\mathrm{MG} \mathrm{V} \cdot \mathrm{IV}$ & $8(26.7 \%)$ & $192(48.2 \%)$ \\
\hline MG III & $10(33.3 \%)$ & $116(29.1 \%)$ \\
\hline MG II $\cdot \mathrm{I}$ & $12(40.0 \%)$ & $90(22.6 \%)$ \\
\hline 計 & $30(100 \%)$ & $398(100 \%)$ \\
\hline
\end{tabular}

表11 Ultrasonography 診断

\begin{tabular}{c|c|c}
\hline US 診断 & 浸潤性小葉癌 & 浸潤癌 \\
\hline US V ・ IV & $14(48.3 \%)$ & $184(45.9 \%)$ \\
US IlI & $13(44.8 \%)$ & $156(38.9 \%)$ \\
US II $\cdot$ I & $2(6.9 \%)$ & $61(15.2 \%)$ \\
\hline 計 & $29(100 \%)$ & $401(100 \%)$ \\
\hline
\end{tabular}

表12 Thermography 診断

\begin{tabular}{c|c|c}
\hline TG 診断 & 浸潤性小葉癌 & \multicolumn{1}{|c}{ 浸潤癌 } \\
\hline TG V $\cdot$ IV & $9(30.0 \%)$ & $131(32.0 \%)$ \\
TG III & $5(16.7 \%)$ & $89(21.8 \%)$ \\
TG II $\cdot$ I & $16(53.3 \%)$ & $189(46.2 \%)$ \\
\hline 計 & $30(100 \%)$ & $409(100 \%)$ \\
\hline
\end{tabular}

$40.0 \%$ と浸潤癌の $22.6 \%$ より多かったが, 有意差は認 めなかった。

3) Ultrasonography 診断（表11）

小葉癌はUltrasonography で USV，あるいは USIV と診断された割合は $48.3 \%$ ，浸潤癌の $45.9 \%$ と比べてやや多く，また，USII，あるいはUSI と診断 された割合は $6.9 \%$ と浸潤癌の $15.2 \%$ に比へて少ない 傾向がみられたが，有意差は認めなかった。

\section{4) Thermography 診断（表12）}

小葉癌は thermography で TGV，あるいは TGIV と診断された割合は $30.0 \%$ ，浸潤癌の $32.0 \%$ とはほ とんど差がみられなかった. TGII，あるいは TGI と診 断された割合は $53.3 \%$ と浸潤癌の $46.2 \%$ りやや多 かったが，有意差は認めなかった。

5）穿刺吸引細胞診（表13）

小葉癌は穿刺吸引細胞診で class $\mathrm{V}$ ，あるいは class IV と診断された割合は $75.0 \%$ あったが，浸潤癌は $94.2 \%$ と有意（p<0.001）に高かった. class III と診 断された割合は小葉癌は $14.3 \%$ と浸潤癌の3.0\%より 有意 $(\mathrm{p}<0.05)$ に多かった。 
表13 穿刺吸引細胞診 $(A B C)$

\begin{tabular}{|c|c|c|}
\hline ABC 診断 & 浸潤性小枼癌 & 門潤癌 \\
\hline class $\mathrm{V} \cdot \mathrm{IV}$ & $21(75.0 \%)$ & $309(94.2 \%)^{* *}$ \\
\hline class III & $4(14.3 \%)$ & $10(3.0 \%)$ \\
\hline class II $\cdot$ I & $3(10.7 \%)$ & $9(2.7 \%)$ \\
\hline 計 & $28(100 \%)$ & $328(100 \%)$ \\
\hline
\end{tabular}

表14 浸潤性小葉癌の触診と穿刺感との比較

\begin{tabular}{c|c|c}
\hline 診断名 & 触 診 & 穿刺感 \\
\hline 乳癌 & $6(20.0 \%)$ & $22(73.3 \%) * *$ \\
乳癌疑い & $15(50.0 \%) * *$ & $1(3.3 \%)$ \\
線維腺腫 & 0 & $1(3.3 \%)$ \\
乳腺 症 & $7(23.3 \%)$ & $3(10.0 \%)$ \\
その他 & $1(3.3 \%)$ & 0 \\
診断なし & $1(3.3 \%)$ & $3(10.0 \%)$ \\
\hline 計 & $30(100 \%)$ & $30(100 \%)$ \\
\hline **p<0.001
\end{tabular}

6）浸潤性小葉癌の触診と穿刺感の比較（表14）

触診と腫瘤に穿刺針を刺入する際に感じる穿刺感に よる診断とを比較した。触診で乳癌と診断した割合は $20.0 \%$ あったが，穿刺感では73.3\%と有意 $(p<$ 0.001)に高率であった。乳癌の疑いと診断した割合は 触診では $50.0 \%$ あって，穿刺感の $3.3 \%$ よ有意 (p<0.001) に高かった.

\section{考 察}

1941年, Foote とStewart ${ }^{31}$ とって最初に報告され た小葉癌は，一般乳癌が乳管上皮から発生するのに対 して，小葉上皮と呼ばれる小葉内細乳管上皮から発生 する特殊な癌で，その浸潤型が浸潤性小葉癌である。 小葉癌は欧米で多く，本邦では少ないと言われている が"，本邦の報告で発生頻度をみると，10年位前は $1 \%{ }^{4)} 2 \%$ 程度であったものが, 最近では $3.5 \%$ " ４.0\%7) と増加傾向がみられる.われわれの過去 10 年 間の症例中では $6.2 \%$ あったた.小葉癌が増加してきた 理由としては, 食生活など生活習慣の欧米化につれて， 発生する乳癌も欧米化してきていることが挙げられて いるがり，病理医が小葉癌に着目するようになったこ とも影響していると考える。葉癌は野口ら 乳癌の両側発生率が1.5\%であったのに対して，4.3\% であったと報告しているなど，一般乳癌と比べて両側 発生が多いと言われている8．われわれの両側性乳癌 6 例中では 2 例が両側ともに浸潤性小葉癌であり，1
側が浸潤性小葉癌で，他側が他の浸潤癌であったもの が 2 例，両側ともに浸潤性乳管癌であったものが 2 例 であった。また，多中心性に発生する傾向もみられる との報告6)昍もあ。

年齢別頻度をみると，われわれの浸潤性小葉癌では 40 歳代が圧倒的に多く, 平均年齢は50.5歳で，その他 の浸潤癌の52.7藏よりやや若い傾向がみられ，野口 ら ${ }^{5}$ も一般乳癌の 49.1 歳に対して, 浸潤性小葉癌は

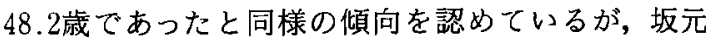
ら ${ }^{4}$ は逆に，全乳癌の平均年齢が48.3歳であったのに 対して浸潤性小葉癌は50.7歳であったと報告してい ろ.いずれにしても, 浸潤性小葉癌と他の乳癌との間 に著しい年齢の差は認められなかった。

われわれの症例では腫瘤の大きさはその他の浸潤癌 と比べて大きいものが多い傾向がみられた。浸潤性小 葉癌の中には腫瘤を形成しないで乳腺内をビマン性に 浸潤し，かなり進行するまで反対側の正常乳腺よりゃ や硬く触れる程度の症例があるので, 腫瘤範囲の決定 が難しく，腫瘤径の計測が大きくなりがちなことも影 響していると考える。

浸潤性小葉癌の癌型割面肉眼分類をみると，浸潤型 が圧倒的に多かったが，その他の浸潤癌と比べると限 局型が少なく，分類不能型が多かった。これらの所見 からもビマン浸潤型が多いことが視われる。総括的に は浸潤性小葉癌はその他の浸潤癌よりビマン浸潤型が 多く，臨床的には進行している症例が多い印象を受け たが，組織学的にはリンパ節転移を認めないものが多 く，一般には，予後が良いと推測された。坂元ら゙は乳 癌全体の 5 生率が $75.7 \%, 10$ 生率が62.8\%であったの に対して，浸潤性小葉癌は，それぞれ $88.9 \%$ と $76.9 \%$ であって，良好な転帰をとるものが多いと述べている． しかし，浸潤性小葉癌には晚期再発例が多いことから， 長期間の経過観察を勧めている。

つぎに，浸潤性小葉癌の各種診断法による診断学的 特徵についてみると，浸潤性小葉癌は他の浸潤癌と比 べて触診で乳癌と確診することが難しい症例が多く， 乳癌の疑いとした症例の方が多かった．腫溜を形成し ないでビマン性に浸潤発育する症例が多いことによる と考える. mammography（以下 MG）では浸潤性小 葉癌を $\mathrm{MGV}, \mathrm{IV}$ と診断した割合はその他の浸潤癌よ り少なく, MGII，I と診断した割合が多かった。それ に対して ultrasonography (以下 US) では浸潤性小葉 癌をUSV, IV と診断した割合はその他の浸潤癌と変 わらなかったが，USII，I と診断した割合は MGより 
かなり少なかった。したがって，浸潤性小葉癌の診断 にはMGよりUSの方が有用であることが䚐われた。 杉谷ら”は浸潤性小葉癌51例中, 41例, 72\%を初回診断 のMGで乳癌と診断したと，非常に高い診断率を報告 しているが，それでも，浸潤性小葉癌を MGやUSで 腫瘤像として捉えられず，乳腺症として経過観察した 後, 触診上乳房全体の縮小硬化と言った変化や腋窩り ンパ節転移を契機に進行例として診断が確定されるこ とがあると述べている．また，松江ら9も述べている が, 浸潤性小葉癌を MGやUS で硬癌と区別すること は困難であると思われる. thermography 診断は浸潤 性小葉癌とその他の浸潤癌の間に差がみられなかっ た. 穿刺吸引細胞診 (aspiration biopsy cytology 以下 $\mathrm{ABC}$ と略)は乳癌の診断において信頼度の高い検査法 である゙2. ABCでその他の浸潤癌を class IV・V と診 断した割合は $94.2 \%$ と高率であった。これに対して浸 潤性小葉癌は75.0\%と低かったが，他の検查法に比べ ると有意に高かった。ABCで浸潤性小葉癌の正診率が 低かった理由は，小葉癌は間質内をビマン性に浸潤す るので，穿刺吸引に際して診断に絶えうる十分な細胞 量が採取しにくく，また，癌細胞の異型が少なく，小 型であるので悪性判定が困難であることが挙げられ る.腫瘤（硬結）を触れた際に手に受ける感じは触診 であるが，穿刺吸引細胞診を行う際，腫瘤（硬結）に 穿刺針を刺入した時に手に受ける感じがある。われわ れはこの感じに，(1)吸引物の性状，(2)吸引物による穿 刺針の詰まり具合を加味して穿刺感として診断してい る.

穿刺感を要約すると, 浸潤性充実腺管癌は硬いが, 針を刺しやすく，吸引物が多い.硬癌は特に硬く,ジャ キジャキとした感じで刺さる，吸引物は多くないが， その気で吸引すればかなり採取できる。浸潤性乳頭腺 管癌は柔らかく細胞成分の多い線維腺腫との区別が難 しい。線維腺腫でも線維成分が多い場合は刺しにくく， 針に粘り着くように感じられる.乳腺症は生ゴムを刺 すようにキョロキョロして針が刺しにくい上に，刺 さった針も抜きにくく，吸引物も少ない，浸潤性小葉 癌に刺した感じは硬癌と似ている．穿刺感によって癌 の組織型を推定することは必ずしも容易ではないが, 癌としての診断はかなり信頼できると考えている．他 の組織型では $\mathrm{ABC}$ の方が悪性の診断率が高い中で浸 潤性小葉癌のみは穿刺感の方が高かったことは既に報
告したが2), 今回, 触診と比較しても乳癌の確診率は高 かった。したがって, 乳腺疾患の診断に際しては浸潤 性小葉癌も念頭に扔き，穿刺感と参考にして対処する ことが診断の遅延を招かないためにも大切である.

結 語

浸潤性小葉癌30例とその他の浸潤癌419例を臨床病 理学的および診断学的に比較検討した. 浸潤性小葉癌 は腫瘤の大きさ，病期などからみると，進行した症例 が多い印象を受けたが, リン八゚節転移陰性例が多く, 予後が良いことが推測された。診断学的には一般乳癌 と比べて触診で確診することは難しく， mammographyより ultrasonographyの方が有用であることが 判明した. 穿刺吸引細胞診が最も有用であるが, 穿刺 感による診断も重要であることが示唆された。

本論文の要旨は第56回日本臨床外科医学会総会において 発表した。

\section{文献}

1）坂元吾偉：乳腺腫瘍病理アトラス. 第 I 版, 篠原出 版, 東京, $1987, \mathrm{p} 58-62$

2）小池綏男, 寺井直樹, 丸山雄造他：乳癌の穿刺吸引 細胞診一特に誤陰性例の検討一. 日臨外医会誌 $54: 865-873,1993$

3) Foote FW Jr, Stewart FW: Lobular carcinoma in situ. Amer J Pathol 17: 491-496, 1941

4）坂元吾偉, 菅野晴夫, 深見敦夫他: 乳腺の小葉癌. 癌の臨 $22: 449-456,1976$

5）野口眞三郎, 和田富雄, 西沢征夫他：乳腺小葉癌 23 例の臨床病理学的検討一組織学的亜型と粘液産生 能について一，日癌治㙩会誌 18：1831-1839, 1983

6）福内 敦, 児玉孝也, 田中礼子他：両側にしかも一 側ては多中心性に発生した乳腺小葉癌の 1 例。日 臨外医会誌 $50: 1548-1550,1989$

7）杉田 瓶, 吉本賢隆, 岩瀬拓士他：浸潤性小葉癌の マンモスグラフィー像。乳癌の臨 $9: 603-609$, 1994

8）小川秀彰, 荻田征美, 生田圭司他：乳腺小葉癌の臨 床病理学的検討。日臨外医会誌 $54: 1712-1715$, 1993

9）松江寛人，廣田映五，村松幸男他：乳腺診断アトラ ス $\mathrm{X}$ 線·超音波と病理. 第 1 版, 金原出版, 東京, 1988, p156-157 


\title{
CLINICOPATHOLOGICAL AND DIAGNOSTIC STUDIES OF INVASIVE LOBULAR CARCINOMAS COMPARED WITH OTHER INVASIVE CARCINOMAS OF THE BREAST
}

\author{
Yasuo KOIKE, Naoki TERAI, Toru WAKABAYASHI and Shin-ichi TSUCHIYA* \\ Department of Cancer Detection and Pathology*, Nagano Cancer Center
}

Thirty female patients with invasive lobular carcinoma and 419 with other invasive carcinoma of the breast who were detected at the breast clinic of Nagano Cancer Center on an ambulant basis during the past 10 years and 3 months were retrospectively compared for clinicopathological and diangnostic factors.

The former group was a little younger in average age than the latter group. Judged from the tumor size, clinical stage and other factors, more advanced cases were involved in the former group than in the latter group. But the cases with lymph node metastasis were fewer in the former group than in the latter group.

Invasive lobular carcinomas presented difficulty in diagnossis by palpation compared to other invasive carcinomas. Ultrasonography was more useful than mammography to diagnose invasive lobular carcinoma as malignancy.

Diagnostic accuracy rate of invasive lobular carcinomas (75.0\%) was statistically lower than that of other invasive carcinomas $(94.2 \%)$ by aspiration biopsy cytology. But this rate was statistically higher than the rates of other diagnostic methods.

It was suggested that the feelings at needle insertion into invasive lobular carcinoma tissues were useful for malignant diagnosis.

From the above results, we would emphasize that we should keep a possible occurence invasive lobular carcinoma in mind and refer the feelings at needle insertion into tumorous tissues for the diagnosis of the mammary disorders. 